\title{
Pengaruh Penambahan Kitosan Terhadap Pertumbuhan Rhizopora mucronata dengan Konsentrasi Berbeda di Tambak Desa Mangunharjo, Semarang
}

\author{
Ayuk Yasinta, Agus Hartoko, dan Suryanti*)
}

\author{
Jurusan Perikanan, Fakultas Perikanan dan Ilmu Kelautan, Universitas Diponegoro \\ Jl. Prof. H. Soedharto, SH, Tembalang Semarang. 50275 Telp/Fax (024) 7474698
}

\begin{abstract}
Abstrak
Rhizophora mucronata adalah salah satu species mangrove, species ini banyak ditanam untuk menangulangi abrasi. Mangrove adalah vegetasi hutan yang tumbuh diantara garis pasang surut tumbuhan yang hidup diantara laut dan daratan. Metode penelitian yang digunakan adalah metode eksperimental. Penelitian ini dilaksanakan pada bulan Desember 2011 sampai Maret 2012. Lokasi penelitian adalah pematang antara tambak budidaya ikan dan pembibitan mangrove. Tujuan dari penelitian ini adalah untuk mengetahui pengaruh pemberian kitosan terhadap pertumbuhan Rhizophora mucronata sehingga dapat digunakan untuk mendapatkan konsentrasi terbaik sebagai acuan pembibitan. Rata-rata pertumbuhan tinggi pucuk Rhizopora mucronata $(\mathrm{cm})$ berdasarkan nilai $R^{2}$ terbesar yaitu 0,998 dan pertambahan panjang dan lebar bibit Rhizopora mucronata $(\mathrm{cm})$ yang terbesar 0,895 pada konsentrasi 10 ppm. Uji $t$ dilakukan untuk melihat pengaruh penambahan kitosan terhadap pertumbuhan dengan membandingkan kontrol dengan perlakuan, hasilnya $F$ hitung $<F$ tabel. Perbandingan kontrol dengan konsentrasi 10 ppm F hitung $-3,822)<F$ tabel 1,782 kontrol dengan konsentrasi 15 ppm F hitung -2,779) < F tabel 1,782 kontrol dengan konsentrasi 33 ppm F hitung -3,223) < F tabel 1,782. Berdasarkan analisis data diatas dapat disimpulkan bahwa tidak ada pengaruh nyata antara penambahan kitosan dengan rata-rata pertumbuhan Rhizopora mucronata, dari kesimpulan tersebut maka tidak didapatkan konsentrasi yang terbaik digunakan untuk pembibitan.
\end{abstract}

Kata Kunci: Konsentrasi kitosan, Pertumbuhan, Rhizopora mucronata

\begin{abstract}
Rhizophora mucronata is one species of mangrove, species are widely planted to overcome abrasion. Mangrove is the vegetation that grows at tidal zone that live between the sea and land. The method used in this study is an experimental method. The research were implemented on December 2011-March 2012. The purpose of this study were determine effect of chitosan addition on the growth of Rhizophora mucronata so it can be used to obtain the best concentration as a reference seedlings. Study site is the embankment of fish farming pond and mangrove seedlings. Average height growth Rhizophora mucronata shoots $(\mathrm{cm})$ that is based on the largest value of $R^{2}$ is 0,998 and width of seeds Rhizopora mucronata $(\mathrm{cm})$ which had the largest correlation value 0.895 thing happened on the chitosan concentration of 10 ppm. T test conducted to see the effect of adding chitosan on growth by comparing control with treatment, results $F$ hitung $<F$ tabel. Comparison of control with a concentration of 10 ppm $F$ hitung $-3,822)<F$ tabel 1,782 control with a concentration of 15 ppm $-2,779<F$ tabel 1,782 control with a concentration of 33 ppm $F$ hitung $-3,223<F$ tabel 1,782. Based on the analysis of the above data it can be concluded that there is no significant effect between the addition of chitosan with an average growth of Rhizophora mucronata, of this conclusion it is not obtained concentration best for the breed.
\end{abstract}

Keywords: Concentration of chitosan, Growth, Rhizopora mucronata

\section{Pendahuluan}

Mangrove adalah vegetasi hutan yang tumbuh di antara garis pasang surut tumbuhan yang hidup diantara laut dan daratan, sehingga hutan mangrove dinamakan juga hutan pasang (Saparinto, 2007). Rhizophora mucronata atau banyak juga yang menyebut dengan bangka hitam, dongoh korap, bakau hitam, bakau korap, bakau merah, jankar, lenggayong, belukap, lolaro. Salah satu species mangrove dengan ketinggian mencapai $27 \mathrm{~m}$, jarang melebihi $30 \mathrm{~m}$, bagian batang memiliki diameter hingga $70 \mathrm{~cm}$ dengan kulit kayu berwarna gelap hingga hitam dan terdapat celah horizontal.

${ }^{*}$ Penulis Penanggung Jawab 
Mangrove memiliki peranan penting dalam melindungi pantai dari gelombang, angin dan badai. Tegakan mangrove dapat melindungi pemukiman, bangunan dan pertanian dari angin kencang atau intrusi air laut. Mangrove juga terbukti memainkan peran penting dalam melindungi pesisir dari gempuran badai (Giezen et al., 2006). Rusaknya kondisi mangrove menimbulkan berbagai permasalahan terutama abrasi yang terjadi hampir di seluruh pantai utara Jawa. Mengingat besarnya kerugian akibat rusaknya mangrove, maka penting dikembangkan kegiatan penanaman mangrove, terutama diluar kawasan hutan. Agar penanaman berjalan dengan baik dan berhasil, masyarakat setempat haruslah terlibat secara penuh mulai dari perencanaan kegiatan sampai pada pemeliharaan tanaman (Khazali, 1999).

Menurut Departemen Kelautan dan Perikanan (2000), dalam Rochima (2008), wilayah perairan Indonesia merupakan sumber cangkang hewan invertebrate laut berkulit keras (Crustacea) yang mengandung kitin secara berlimpah. Kitin yang terkandung dalam Crustacea berada dalam kadar yang cukup tinggi berkisar 20 - 60\% tergantung spesies.Kulit udang merupakan limbah dalam industri pengolahan udang yang porsinya mencapai $30-70 \%$. Salah satu pemanfaatan dari kulit udang adalah dengan diproses menjadi kitosan. Kitosan merupakan polielektrolit kationik dan polimer berantai panjang, mempunyai berat molekul besar dan reaktif karena adanya gugus amina dan hidroksil yang bertindak sebagai donor elektron (Ibrahim et al., 2009).

Pemanfaatan kepiting umumnya hanya daging saja yang diambil sedangkan cangkang dibuang dan merupakan limbah pengalengan kepiting yang belum diolah secara maksimal, padahal cangkang kepiting mengandung senyawa kitin yang cukup tinggi. Penggunaan kitin dibatasi oleh sifat-sifat yang tidak larut dan sulit dipisahkan dengan bahan lain terikat terutama dengan protein, sehingga untuk pemanfaatan kitin perlu diubah terlebih dahulu menjadi kitosan. Manfaat kitin dan kitosan di berbagai bidang industri modern cukup banyak, diantaranya dalam industri farmasi, biokimia, bioteknologi, biomedikal, pangan, gizi, kertas, tekstil, pertanian, kosmetik, membran dan kesehatan. Disamping hal tersebut, kitin dan kitosan serta turunannya mempunyai sifat sebagai bahan pengemulsi koagulasi dan penebal emulsi. Hal tersebut dijelaskan oleh Marganof (2003) dalam Restuati (2009).

Penelitian ini bertujuan mengetahui pengaruh pemberian kitosan terhadap pertumbuhan Rhizopora mucronata, guna memanfaatkan kitosan sebagai limbah industri hasil perikanan.

\section{Bahan dan Metode}

Bahan yang digunakan dalam penelitian ini antara lain bibit Rhizopora mucronata dan kitosan. Kitosan terbuat dari limbah cair yang dibuat dengan menggunakan limbah padat pengolahan ikan (kepala, sisik, kulit dan tulang) yang diproses sebagai pengganti limbah cair industri perikanan.

Prosedur penelitian dimulai dengan penentuan lokasi, dimana lokasi tersebut mudah dijangkau serta jauh dari bibir pantai agar bedeng terlindung dari hempasan ombak dan yang lebih penting bibit yang sudah disemprot dengan konsentrasi kitosan yang berbeda tidak saling tercampur. Langkah berikutnya dilakukan penyemprotan kitosan dengan berbagai konsentrasi pada bibit mangrove mengikuti langkah-langkah berikut:

1. Bibit mangrove dari jenis Rhizopora mucronata diletakkan di dalam bedeng persemaian masing-masing 9 buah untuk setiap konsentrasi perlakuan, yang sebelumnya bibit sudah ditanam dalam polibag;

2. Kitosan diencerkan dengan aquades hingga diperoleh konsentrasi 33 ppm, 15 ppm, dan 10 ppm;

3. Tinggi pucuk, lebar dan panjang daun bibit mangrove diukur dengan pengaris setiap satu minggu sekali pada setiap konsentrasi selama 3 (tiga) bulan, dan

4. Sampel bibit mangrove diberi perlakuan disemprot dengan kitosan denga konsentrasi berbeda setiap satu minggu sekali selama 3 (tiga) bulan.

\section{Hasil dan Pembahasan}

Tabel 1. Data pertumbuhan setelah pengukuran didapatkan hasil sebagai berikut:

\begin{tabular}{|c|c|c|c|c|}
\hline Waktu & Kontrol 0 & Konsentrasi 10 & Konsentrasi 15 & Konsentrasi 33 \\
\hline 0 & 1.051 & 1.144 & 1.025 & 1.074 \\
\hline 1 & 1.051 & 1.444 & 1.025 & 1.074 \\
\hline
\end{tabular}




\begin{tabular}{|c|c|c|c|c|}
\hline 2 & 1.059 & 1.151 & 1.033 & 1.085 \\
\hline 3 & 1.096 & 1.166 & 1.051 & 1.096 \\
\hline 4 & 1.144 & 1.188 & 1.103 & 1.170 \\
\hline 5 & 1.214 & 3.135 & 1.162 & 1.266 \\
\hline 6 & 1.307 & 3.503 & 1.355 & 1.448 \\
\hline 7 & 4.092 & 4.053 & 4.582 & 5.492 \\
\hline 8 & 3.944 & 5.025 & 5.403 & 5.670 \\
\hline 9 & 4.751 & 6.154 & 6.085 & 6.777 \\
\hline 10 & 5.303 & 6.077 & 6.187 & 6.987 \\
\hline 11 & 5.749 & 6.96 & 6.814 & 8.017 \\
\hline 12 & 6.490 & 8.129 & 8.222 & 9.118 \\
\hline
\end{tabular}

Uji T Sampel Independent

a. Kontrol dengan konsentrasi $10 \mathrm{ppm}$

\begin{tabular}{|l|c|c|}
\hline \multicolumn{2}{|l|}{ t-Test: Paired Two Sample for Means } & \\
\hline & Variable 1 & Variable 2 \\
\hline Mean & 2.942969231 & 3.779984615 \\
\hline Variance & 4.553620462 & 6.245402751 \\
\hline Observations & 13 & 13 \\
\hline Pearson Correlation & 0.954071175 & \\
\hline Hypothesized Mean Difference & 0 & \\
\hline df & 12 & \\
\hline t Stat & -3.82287616 & \\
\hline P(T<=t) one-tail & 0.001213384 & \\
\hline t Critical one-tail & 1.782287548 & \\
\hline P(T<=t) two-tail & 0.002426768 & \\
\hline t Critical two-tail & 2.178812827 & \\
\hline
\end{tabular}

b. Kontrol dengan konsentrasi 15 ppm

\begin{tabular}{|c|c|c|}
\hline \multicolumn{2}{|c|}{ t-Test: Paired Two Sample for Means } & \multirow[b]{2}{*}{ Variable 2} \\
\hline & Variable 1 & \\
\hline Mean & 2.942969231 & 3.465807692 \\
\hline Variance & 4.553620462 & 7.675106712 \\
\hline Observations & 13 & 13 \\
\hline Pearson Correlation & 0.995363533 & \\
\hline Hypothesized Mean Difference & 0 & \\
\hline $\mathrm{df}$ & 12 & \\
\hline t Stat & -2.779692661 & \\
\hline $\mathrm{P}(\mathrm{T}<=\mathrm{t})$ one-tail & 0.008329942 & \\
\hline t Critical one-tail & 1.782287548 & \\
\hline $\mathrm{P}(\mathrm{T}<=\mathrm{t})$ two-tail & 0.016659885 & \\
\hline t Critical two-tail & 2.178812827 & \\
\hline
\end{tabular}

c. Kontrol dengan konsentrasi 33 ppm

\begin{tabular}{|c|c|c|}
\hline \multicolumn{2}{|c|}{ t-Test: Paired Two Sample for Means } & \multirow[b]{2}{*}{ Variable 2} \\
\hline & Variable 1 & \\
\hline Mean & 2.942969231 & 3.867523077 \\
\hline Variance & 4.553620462 & 9.98408009 \\
\hline Observations & 13 & 13 \\
\hline Pearson Correlation & 0.998714764 & \\
\hline Hypothesized Mean Difference & 0 & \\
\hline $\mathrm{df}$ & 12 & \\
\hline t Stat & -3.223129968 & \\
\hline $\mathrm{P}(\mathrm{T}<=\mathrm{t})$ one-tail & 0.00365595 & \\
\hline t Critical one-tail & 1.782287548 & \\
\hline
\end{tabular}




\begin{tabular}{|l|l|l|}
\hline $\mathrm{P}(\mathrm{T}<=\mathrm{t})$ two-tail & 0.007311899 & \\
\hline $\mathrm{t}$ Critical two-tail & 2.178812827 & \\
\hline
\end{tabular}

Uji t atau uji beda digunakan untuk menganalisa apakah penambahan kitosan berpengaruh secara nyata atau tidak. Dilihat dari dari output uji t pada tabel t-Test Paired Two Sample for Means jika $\mathrm{T}$ hitung $<\mathrm{T}$ tabel berarti $\mathrm{H}_{0}$ diterima dan $\mathrm{H}_{1}$ ditolak berlaku juga sebaliknya (Ariyoso, 2009). Dari uji t perbandingan kontrol dengan konsentrasi 10 ppm didapatkan $T_{\text {hitung }}-3,822<T_{\text {tabel }} 1,782$ sampel kontrol dengan konsentrasi 15 ppm $T_{\text {hitung }}-2,779<T_{\text {tabel }} 1,782$ dan kontrol dengan konsentrasi 33 ppm didapatkan $T_{\text {hitung }}-3,223<\mathrm{T}_{\text {tabel }} 1,782$. Sesuai kaidah penafsiran diatas maka dapat disimpulkan bahwa $\mathrm{H}_{0}$ diterima dan tolak $\mathrm{H}_{1}$ yang berarti penambahan kitosan dengan 3 (tiga) perlakuan yaitu konsentrasi $10 \mathrm{ppm}$, kosentrasi $15 \mathrm{ppm}$ dan 33 ppm tidak ada pengaruh nyata terhadap pertumbuhan bibit Rhizopora mucronata. Hal tersebut terjadi karena pertumbuhan antar perlakuan tidak jauh berbeda rentan nilainya. Dengan demikiantidak didapatkan konsentrasi yang terbaik untuk pembibitan Rhizopora mucronata.

Tabel 2. pH Tanah dan Salinitas Air

\begin{tabular}{|c|c|c|}
\hline \multirow{2}{*}{ Waktu (minggu) } & \multicolumn{2}{|c|}{ Parameter } \\
\cline { 2 - 3 } & $\mathrm{pH}$ tanah & Salinitas (ppt) \\
\hline 0 & 6 & 23 \\
\hline 1 & 7 & 21 \\
\hline 2 & 7 & 23 \\
\hline 3 & 7 & 18 \\
\hline 4 & 7 & 23 \\
\hline 5 & 7 & 17 \\
\hline 6 & 7 & 18 \\
\hline 7 & 7 & 23 \\
\hline 8 & 7 & 23 \\
\hline 9 & 7 & 23 \\
\hline 10 & 7 & 23 \\
\hline 11 & 7 & 21 \\
\hline 12 & 7 & 23 \\
\hline
\end{tabular}

Hasil pengukuran $\mathrm{pH}$ tanah, sebesar $6-7$ kondisi tanah dikatakan basa. Derajat $\mathrm{pH}$ dalam tanah dengan nilai tersebut baik digunakan untuk pembibitan karena unsur hara akan mudah diserap tanaman yang disebabkan pH 6 - 7 unsur hara akan mudah larut dalam air. Kondisi $\mathrm{pH}$ tanah juga dapat digunakan untuk menentukan perkembangan mikroorganisme dalam tanah. Pada $\mathrm{pH} 6$ - 7 jamur dan bakteri pengurai bahan organik akan tumbuh dengan baik. Hasil pengukuran didapatkan salinitas berkisar antara 17 - 23 ppt, nilai salinitas terendah adalah 17 dan salinitas tertinggi sebesar 23 ppt. Kusmana (1983) dalam Hutahaean (1999) menyatakan kisaran salinitas untuk Rhizophora mucronata adalah 12 - 30 ppt. Faktor penurunan salinitas dipengaruhi oleh adanya curah hujan tinggi dalam jangka waktu yang cukup lama.

Dari hasil analisis didapatkan bahan organik tanah sebesar 8,94\% menurut Reynold, 1971 nilai tersebut masih tergolong dalam kategori sedang, bukan berarti terhindar dari dampak negatif. Bahan organik tanah yang tergolong sedang disebabkan karena disekitar lokasi pembibitan Rhizopora mucronata, tanah telah tercampur dengan buangan limbah rumah tangga yang berasal dari pemukiman dengan banyak sampah plastik. Hanafiah (2005) dalam Hermawan (2011), bahan organik tanah biasanya menyusun sekitar 5\% bobot total tanah, meskipun hanya sedikit tetapi memegang peran penting dalam munentukan kesuburan tanah baik secara fisik, kimiawi maupun secara biologis tanah. Sebagai komponen tanah yang berfungsi media tumbuh, maka bahan organik juga berpengaruh secara langsung terhadap perkembangan dan pertumbuhan tetanaman dan mikrobia tanah, yaitu sebagai sumber energi, hormon, vitamin dan senyawa perangsang tumbuh lainnya. Secara kimiawi bahan organik tanah tersusun oleh $44 \% \mathrm{C}, 8 \% \mathrm{H}, 40 \% \mathrm{O}$ dan $8 \%$ mineral.

Hasil pengukuran tekstur tanah dengan metode saringan, prosentase terbesar substrat yang mendominasi adalah Silt (lanau) sebesar 95,94\% dan sisanya terdiri dari jenis substrat pasir, Clay (lempung dan Gravel. Substrat yang sesuai untuk pertumbuhan Rhizopora mucronata adalah lanau, yang juga banyak ditemukan di ekosistem Rhizopora mucronata di tempat lain. Lear dan Turner (1977) dalam Soeroyo dan Suyarso (1990), mengemukakan bahwa tanah mangrove mempunyai ciri-ciri selalu basah, mengandung garam dan kandungan oksigen sedikit, berbutir-butir dan kaya akan bahan organik. Kebutuhan-kebutuhan tersebut yang terus menerus merupakan cyclus di daerah pasang surut. Bahan organik yang terdapat dalam tanah berasal dari perombakan sisa tumbuhan yang diproduksi oleh mangrove tersebut. Munculnya serasah secara lambat laun akan hancur di bawah kondisi sedikit asam oleh mikro-arganisme seperti bakteri, jamur dan kemungkinan algae. Tanah mangrove juga terdapat sedimen-sedimen halus atau partikelpartikel pasir, material kasar seperti potongan-potongan batu dan koral, pecahan kulit-kulit kerang, telur dan siput. Biasanya tanah-tanah mangrove kurang membentuk lumpur berlempung dan warnanya bervariasi dari abu-abu muda sampai hitam. Substrat tersebut terbentuk oleh endapan sedimen-sedimen yang terbawa oleh aliran sungai ditambah oleh material-material yang dibawa dari laut pada waktu air pasang. Sedimen-sedimen halus dan material suspense lain 
terbawa oleh aliran sungai dapat mengendap di mangrove disebabkan oleh berkurangnya aliran, turbulensi dan pengaruh koagulasi yang disebabkan oleh pencampuran dengan air laut.

\section{Kesimpulan}

Berdasarkan analisis varians (ANOVA) didapatkan hasil bahwa nilai $\mathrm{F}$ hitung $<\mathrm{F}$ tabel dimana $\mathrm{F}_{\text {hitung }} 0,319<\mathrm{F}_{\text {tabel }}$ 2,798. Dari uji t perbandingan kontrol dengan konsentrasi $10 \mathrm{ppm}$ didapatkan $\mathrm{T}_{\text {hitung }}-3,822<\mathrm{T}_{\text {tabel }} 1,782$ sampel kontrol dengan konsentrasi $15 \mathrm{ppm} \mathrm{T}_{\text {hitung }}-2,779<\mathrm{T}_{\text {tabel }} 1,782$ dan kontrol dengan konsentrasi $33 \mathrm{ppm}$ didapatkan $\mathrm{T}_{\text {hitung }}-3,223<\mathrm{T}_{\text {tabel }} 1,782$. Maka dapat disimpulkan bahwa $\mathrm{H}_{0}$ diterima dan tolak $\mathrm{H}_{1}$ yang berarti penambahan kitosan dengan 3 (tiga) perlakuan yaitu konsentrasi $10 \mathrm{ppm}$, kosentrasi $15 \mathrm{ppm}$ dan $33 \mathrm{ppm}$ tidak ada pengaruh nyata terhadap pertumbuhan bibit Rhizopora mucronata. Dengan demikian maka tidak didapatkan konsentrasi terbaik untuk pembibitan.

\section{Daftar Pustaka}

Ariyoso. 2009. Uji T Berpasangan. Http://www .wordpress.com/2009/11/13/uji-t-berpasangan/. (06 Agustus 2012).

Hutahaean, E. E., Cecep, K dan Helmy, R. D. Studi Kemampuan Tumbuh Anakan Mangrove Jenis Rhizopora mucronata, Bruguiera gimnorrhiza dan Avicennia marina Pada Berbagai Tingkat Salinitas. 1999. Jurnal Manajemen Hutan Tropika, 5(1): 83.

Hermawan, A. A. 2011. Analisis Perbedaan Total Bakteri Tanah Pada Pasang Tertinggi dan Surut Terendah di Perairan Teluk Awur Jepara. Jurusan Perikanan UNDIP, Semarang.

Giezen, W., S, Wulffraat., M, Zieran dan L, Schoaltan. Panduan Pengenalan Mangrove di Indonesia. 2006. Ed. II. Green Coast, Bogor, 21 hlm. (diterjemahkan oleh Noor, R. Y., M, Khazali. dan I.N.N, Suryadiputra).

Khazali, M. 1999. Panduan Teknis Penanaman Mangrove Bersama Masyarakat.Wetlands International - Indonesia Programme. Bogor.

Ibrahim, B., P, Suptijah. dan Prantommy. 2009. Pemanfaatan Kitosan pada Pengolahan Limbah Cair Industri Perikanan. Jurnal Pengolahan Hasil Perikanan, Bogor, 12(2): 155

Reynold, S. C. 1971. Amanual Intoductory Soil Science and Simple Soil Analysis Method. South Pasific, Nouena New Caledonia, $223 \mathrm{hlm}$.

Restuati, M. 2009. Uji Agent Anti Kolesterol Chitosan Dari Kulit Kepiting Dengan Cara Biodegradasi Enzimatik. Dalam: Hutahean, S., Ilyas, S., Rahayu, S., dan Berliani, K. Prosiding Seminar Nasional Biologi Sumatera Utara Tanggal 22 Januari 2011. USU Press, Medan, pp. 630-631.

Rochima, E. 2008. Karakterisasi Kitin dan Kitosan Asal Limbah Rajungan Cirebon Jawa Barat.Jurnal Kitin dan Kitosan, Cirebon, 6(3): 1-3.

Saparinto, C. 2007. Pendayagunaan Ekosistem Mangrove. Effhar dan Dahara Prize, Semarang, $51 \mathrm{hlm}$.

Soeroyo dan Suyarso. 1990. Sifat-sifat Kimia Tanah Mangrove. Jurnal Analisa Tanah Mangrove, Yogyakarta, 4(2): 15. 